\title{
PERSONALITY CORRELATES OF THE RAPIDITY OF PROGRESSION OF RHEUMATOID ARTHRITIS
}

\author{
BY \\ RUDOLF H. MOOS AND GEORGE F. SOLOMON* \\ From the Department of Psychiatry, Stanford University School of Medicine, Palo Alto, California
}

Several recent papers (Moos and Solomon, 1963a, b, 1964) have shown some agreement concerning the particular personality factors possibly related to the onset or course of rheumatoid arthritis. The present paper reports an attempt to discover whether there are relationships between personality variables and the rapidity of progression of rheumatoid arthritis.

There have been, to the authors' knowledge, little or no previous investigations in this field. Three recent comprehensive reviews covering, respectively, the treatment of rheumatoid arthritis (Wright, 1963), the epidemiology of rheumatoid arthritis with particular attention to social and personality factors (Scotch and Geiger, 1962), and the association between rheumatoid arthritis and personality characteristics (Moos, 1964), all failed to report a single study attempting to relate the rapidity of progression of illness to personal or social factors.

Patients with rheumatoid arthritis have been consistently found to show more compliance-subservience, nervousness-restlessness, depression, conservatism-security, and sensitivity (to anger) than various control subjects. They are also apparently

* Formerly consultants to the Rheumatic Disease Group, Department of Medicine, University of California Medical Center, San Francisco, Calif. strongly prone to deny their hostility, and to be self-sacrificing and masochistic, as well as shy, inhibited, perfectionistic, rigid, and moralistic (Moos, 1964; Moos and Solomon, 1963a, b, 1964).

The hypothesis was made that some of these personality factors might differentiate between patients whose disease had progressed relatively rapidly and patients whose disease had progressed relatively slowly. King (1955) had earlier hypothesized a possible relationship between the strictness of ego-control or inhibition of feelings and the severity of arthritis, and King and Cobb (1959) had found some differences between mild and severe arthritic patients.

\section{Subjects}

This study, which was done as a special part of a larger longitudinal family study of rheumatoid arthritis, deals with 49 female arthritic patients; in 32 the disease was classified as "definite" by virtue of fulfilling five or six of the criteria of active rheumatoid arthritis, and in seventeen as "classical" by virtue of fulfilling seven or eight of the criteria established by the American Rheumatism Association (1959).

Table I summarizes the duration of disease, stage of severity of disease, the grade or functional capacity

TABLE I

SEVERITY AND DURATION OF DISEASE, FUNCTIONAL CAPACITY, AND RESULTS OF FII TEST IN ALL PATIENTS

\begin{tabular}{|c|c|c|c|c|c|c|c|}
\hline \multicolumn{2}{|c|}{ Severity of Disease } & \multicolumn{2}{|c|}{ Functional Capacity } & \multicolumn{2}{|c|}{ Duration of Disease } & \multicolumn{2}{|l|}{ FII Test } \\
\hline Stage & No. of Cases & Grade & No. of Cases & Years & No. of Cases* & Result & No. of Cases * \\
\hline 1 & 3 & 1 & 9 & $1-5$ & 11 & Negative & 6 \\
\hline 2 & 23 & 2 & 27 & 6-10 & 15 & Positive $1: 224$ to $1: 448$ & 5 \\
\hline 3 & 19 & 3 & 10 & $11-15$ & 7 & \multirow{2}{*}{ Positive $1: 896$ to $1: 3,584$} & \multirow{2}{*}{11} \\
\hline \multirow[t]{2}{*}{4} & 2 & 4 & 1 & $16-20$ & 5 & & \\
\hline & & & & $>20$ & 10 & Positive $>1: 7,000$ & 17 \\
\hline \multicolumn{2}{|c|}{ Total } & \multicolumn{2}{|r|}{47} & \multicolumn{2}{|r|}{48} & & 39 \\
\hline
\end{tabular}

* The number of cases does not total 49 because of missing data on a few patients. 
manifested by the patient, and the results of the FII test (an agglutination test for the presence of rheumatoid factor in the serum).

Two groups of patients were selected from this larger sample for further study. In one group the rate of progression of the disease had been relatively rapid and in the other relatively slow. Those patients who had had the disease for the longest time but who were still classified in Stages 1 or 2 were in the slow progression group, and those who had had the disease for the shortest time but were already classified in Stages 3 or 4 were in the rapid progression group. The categories of Steinbrocker, Traeger, and Batterman (1949) were used to characterize the stages of disease (early, moderate, severe, and terminal). The eleven patients whose disease had progressed most rapidly were then compared with the eleven whose disease had progressed most slowly. Table II shows the duration and stage of severity of disease for these two groups.

TABLE II

DURATION AND STAGE OF SEVERITY OF DISEASE IN PATIENTS SHOWING FAST AND SLOW PROGRESSION

\begin{tabular}{c|c|c|c|c}
\hline \multirow{2}{*}{$\begin{array}{c}\text { Rate of } \\
\text { Progression }\end{array}$} & \multicolumn{2}{|c|}{ Duration of Disease } & \multicolumn{2}{c}{ Severity of Disease } \\
\cline { 2 - 4 } & Years & $\begin{array}{c}\text { No. of } \\
\text { Cases }\end{array}$ & Stage & $\begin{array}{c}\text { No. of } \\
\text { Cases }\end{array}$ \\
\cline { 2 - 4 } Fast & $\begin{array}{c}1-6 \\
7-12\end{array}$ & 4 & 1 & 0 \\
& $13-18$ & 5 & 2 & 0 \\
& $>19$ & 2 & 3 & 10 \\
& Mean $8 \cdot 5$ & 11 & 4 & 1 \\
\hline Slow & $1-6$ & 0 & & 11 \\
& $7-12$ & 5 & 2 & 1 \\
& $13-18$ & 4 & 3 & 0 \\
& $>19$ & 2 & 4 & 0 \\
\hline
\end{tabular}

The grade of functional capacity was, of course, different. Those in the rapid progression group manifested a greater absolute degree of incapacity than those in the slow progression group; however, the degree of incapacity relative to the objective progression of the disease was the same in both groups.

All patients had completed a questionnaire relating to such variables as age, parents' occupational status, and education. This information made it possible to match the two groups utilized in this study on a number of background variables. It was important to match the two groups by these factors since they have been repeatedly shown to affect responses on psychological tests. Table III shows the close matching achieved between the two groups.

\section{Methods}

A Minnesota Multiphasic Personality Inventory (MMPI) was administered to each patient in the slow and the fast progression groups. The MMPI is a self-administered objectively-scored 566-item questionnaire which has been extensively used in clinical and experimental research (Hathaway and McKinley, 1951; Welsh and Dahlstrom, 1956). Over 200 different scales measuring variables ranging from social and emotional alienation to somatization reaction, denial of symptoms, anxiety reaction, ego strength, ethnocentrism, intellectual efficiency, social introversion, and rigidity, have been empirically derived from these items.

Those scales which had already been shown to differentiate significantly between patients with rheumatoid arthritis and the healthy members of their families (Moos and Solomon, 1964) and those which had been shown to differentiate significantly between patients with a high or low degree of functional capacity relative to the stage of severity of their disease (Moos and Solomon, 1963c) were chosen for comparison. These scales reflected (1) physical symptoms; (2) depression, apathy, lack of motivation; (3) general neurotic symptoms, including alienation from self and others, anxiety, hostility;

TABLE III

BACKGROUND VARIABLES OF PATIENTS SHOWING FAST AND SLOW PROGRESSION

\begin{tabular}{|c|c|c|c|c|c|c|c|c|}
\hline $\begin{array}{c}\text { Rate of } \\
\text { Progression }\end{array}$ & $\begin{array}{l}\text { Average } \\
\text { Age (yrs) }\end{array}$ & $\begin{array}{c}\text { Average } \\
\text { Education (yrs) }\end{array}$ & \multicolumn{2}{|c|}{ Marital Status } & \multicolumn{2}{|c|}{$\begin{array}{l}\text { No. of } \\
\text { Children }\end{array}$} & \multicolumn{2}{|c|}{$\begin{array}{c}\text { Parents' } \\
\text { Occupational Class* }\end{array}$} \\
\hline $\begin{array}{c}\text { Fast } \\
\text { (11 cases) }\end{array}$ & $43 \cdot 4$ & $11 \cdot 8$ & $\begin{array}{l}\text { Single } \\
\text { Married } \\
\text { Widowed, divorced, } \\
\text { separated, and/or } \\
\text { remarried }\end{array}$ & $\begin{array}{l}2 \\
5\end{array}$ & $\begin{array}{l}0-1 \\
2-3 \\
>3\end{array}$ & $\begin{array}{l}6 \\
3 \\
2\end{array}$ & $\begin{array}{l}\text { I } \\
\text { II } \\
\text { III } \\
\text { IV } \\
\text { V }\end{array}$ & $\begin{array}{l}0 \\
3 \\
6 \\
2 \\
0\end{array}$ \\
\hline $\begin{array}{l}\text { Slow } \\
\text { (11 cases) }\end{array}$ & $47 \cdot 9$ & $11 \cdot 2$ & $\begin{array}{l}\text { Single } \\
\text { Married } \\
\text { Widowed, divorced, } \\
\text { separated, and/or } \\
\text { remarried }\end{array}$ & $\begin{array}{l}1 \\
4\end{array}$ & $\begin{array}{l}0-1 \\
2-3 \\
>3\end{array}$ & $\begin{array}{l}4 \\
6 \\
1\end{array}$ & $\begin{array}{r}\text { I } \\
\text { II } \\
\text { III } \\
\text { IV } \\
\text { V }\end{array}$ & $\begin{array}{l}0 \\
3 \\
7 \\
1 \\
0\end{array}$ \\
\hline
\end{tabular}

* Classifications were made according to a modification of the Warner, Meeker, and Eells (1949) seven-grade grouping. 
(4) psychological rigidity; (5) problems of control of impulses; (6) similarity to other "psychosomatic" diseases.

Rationally-derived MMPI scales constructed to measure personality trait dimensions, which, according to previous findings, were particularly prevalent in rheumatoid arthritis, were also scored. All 566 items of the MMPI had been sorted independently by two sorters, who each decided whether an item was relevant to a particular personality trait dimension, and, if relevant, how it should be scored to reflect that dimension. Eleven personality trait scales, including only items on which the two raters agreed, were constructed in this manner.

The detailed procedure by which the personality trait dimensions had been identified from research findings in the literature has been described in a previous paper (Moos and Solomon, 1963a). The dimensions are listed in Table IV.

\section{TABLE IV}

\section{PERSONALITY TRAIT SCALES DERIVED FROM MMPI}

1. Dependency $v$. Denial of dependency, hyperindependence

2. Physical activity $v$. Motor inhibition

3. Duty conscientiousness $v$. Lackadaisicalness

4. Compulsivity, perfectionism $v$. Disorderliness, slovenliness

5. Compliance-subservience $v$. Defiance

. Masochism, self-sacrifice, denial of hostility $v$. Sadism

Conservatism, security $v$. Boldness, willingness to take risks

8. Overconcern about looks, impression $v$. Unconcern about appearance

9. Sensitivity (especially to others' anger) $v$. Insensitivity

10. Busyness $v$. Idleness

11. Emotional lability $v$. Emotional stability

\section{The following are typical examples:}

Item 235: "I have been quite independent and free from family rule", was scored false on the dependent-independent dimension.

Item 138: "Criticism or scolding hurts me terribly", was scored true on the sensitivity-callousness dimension.

Item 493: "I prefer work which requires close attention to work which allows me to be careless", was scored true on the compulsive, perfectionistic dimension.

Item 408: "I am apt to hide my feelings in some things to the point that people may hurt me without their knowing it", was scored true on the masochism-self-sacrifice dimension.

\section{Results}

The comparisons which reached statistical significance $(P<\cdot 05)$ are listed in Table V.

The patients whose disease had progressed relatively slowly scored higher on scales reflecting compliance-subservience, perfectionism, denial of hostility, capacity for status, social responsibility, and social status; whereas those whose disease had progressed relatively rapidly scored higher on scales reflecting physical malfunctioning, general maladjustment, judged anxiety, judged manifest hostility, and imperturbability.

TABLE $\mathrm{V}$

GROUPS OF SCALES SHOWING SIGNIFICANT DIFFERENCES BETWEEN PATIENTS SHOWING SLOW AND FAST PROGRESSION

\begin{tabular}{|c|c|}
\hline Group & Observations \\
\hline I & $\begin{array}{l}\text { Physical symptoms } \\
\text { Physical Malfunctioning }\end{array}$ \\
\hline II & $\begin{array}{l}\text { Depression, apathy, lack of motivation } \\
\text { There were no significantly differentiating scales }\end{array}$ \\
\hline III & $\begin{array}{l}\text { General "neurotic" symptoms } \\
\text { General maladjustment } \\
\text { Judged anxiety } \\
\text { Imperturbability } \\
\text { Judged manifest hostility } \\
\text { * Capacity for status } \\
\text { * Social responsibility } \\
\text { * Social status } \\
\text { * Compulsivity, perfectionism }\end{array}$ \\
\hline IV & Psychological rigidity-None \\
\hline $\mathbf{V}$ & $\begin{array}{l}\text { Problems of control of impulses } \\
\text { Psychopathic deviate } \\
\text { * Compliance, subservience } v \text {. defiance } \\
\text { * Masochism, self-sacrifice, denial of hostility }\end{array}$ \\
\hline VI & $\begin{array}{l}\text { Similarity to other "psychosomatic"conditions } \\
* \text { Ulcer personality }\end{array}$ \\
\hline
\end{tabular}

* The slow progression group scored higher on this scale.

Typical items which also differentiated significantly $(P<\cdot 05)$ between the two groups on these scales include the following:

(1) "During the past few years I have been well most of the time." This item was scored false on the physical malfunctioning scale and was answered false significantly more often by the rapid progression group.

(2) "I feel anxiety almost all the time" and "It makes me nervous to have to wait", were both scored true on the judged anxiety scale and were both answered true significantly more often by the rapid progression group.

(3) "I think most people would lie to get ahead", and "It's all right to get around the law if you don't actually break it", were both scored true on the judged manifest hostility scale and were both answered true significantly more often by the rapid progression group.

(4) "I am apt to pass up something I want to do when others feel that it isn't worth doing", was scored true on the compliance-subservience scale and was answered true significantly less often by the rapid progression group. 
Other typical items differentiating between the two groups include:

(1) "I am apt to hide my feelings in some things to the point that people may hurt me without their knowing it" (scored true on the masochism-selfsacrifice scale and answered true significantly less often by the rapid progression group).

(2) "My parents have often objected to the kind of people I went around with" (scored true on the psychopathic deviate scale and answered true significantly more often by the rapid progression group).

(3) "It wouldn't make me nervous if any members of my family got into trouble with the law" (scored true on the imperturability scale, which reflects, in general, a denial of sensitivity and a proclamation of independence from the opinions of other people, and answered true significantly more often by the rapid progression group).

The ulcer personality scale items, on which the slow progression group scored higher, tend to reflect compliance, shyness, conscientiousness, religiosity, and moralism. Relevant items include:

"I like to go to parties and other affairs where there is lots of loud fun" (scored false);

"I feel like giving up quickly when things go wrong" (scored false);

"Everything is turning out just like the prophets of the Bible said it would";

"I believe in the second coming of Christ";

"I prefer work which requires close attention to work which allows me to be careless."

There were several additional scales on which the rapid progression patients scored higher than the slow progression patients, but not quite to a statistically significant degree. These scales reflected depression, lassitude-malaise, denial of social anxiety, familial discord, authority problems, delinquency, and predjudice.

\section{Discussion}

It is clear that there were differences between the two groups in their responses to the MMPI. The particular differentiating scales strongly suggest that those whose disease progressed more rapidly were beginning to experience vague feelings of ego disorganization and breakdown. Rheumatoid arthritic patients, at least initially, tend to adjust to their disease with stoicism and optimism (Johnson, Shapiro, and Alexander, 1947), and tend to show the particular personality traits of compliance-subservience, masochism, self-sacrifice, perfectionism, rigidity, and moralism. Those whose disease had progressed more rapidly could be differentiated from the others on some of these personality traits. The patients with rapidly progressing disease obtained higher scores on scales reflecting anxiety and manifest hostility, but lower scores on scales reflecting compliance-subservience, compulsivity-perfectionism, masochism-self-sacrifice, social status, and social responsibility. These group differences suggest that the patients with rapidly progressive disease were experiencing an inability to use previously successful coping mechanisms; they were more anxious and depressed, and they were not as well able to utilize the adaptive defences of compliance, compulsivity, and suppression of anger as were those in the slow progression group.

The patients with rapidly progressive disease appeared to be making a strong but relatively unsuccessful attempt to keep their impulses under control. On the one hand they attempted to deny their anxiety in social situations and affirm their independence from other people (imperturbability) and on the other hand they obtained higher scores on the judged anxiety scale and lower scores on the social status and responsibility scales. It is probable that these patients felt more isolated, and lonely, and alienated from others, that they received less social support in attempting to cope with their disease; that they were experiencing feelings of ego disorganization, with a concomitant increase in anxiety and depression and a decrease in the ability to continue their former modes of adaptation and coping; that they were still strongly attempting to regain ego control through increased defensiveness and partial denial of anxiety. The breakdown of prior adaptive modes appears to manifest itself most strongly around additional problems with the control of impulses.

The relationship of personality factors to the rapidity of progression of disease has been studied in other disease states, including multiple sclerosis and cancer.

Personality characteristics of passive dependency, submission, compliance, absence of awareness of inner tension, excessive cordiality and friendliness, immaturity, and depression have been linked to patients suffering from multiple sclerosis. Many investigators have hypothesized relationships between exacerbations and relapses and emotional shock or stress, precipitated by severe mental conflict, financial worries, increased responsibilities, an unhappy home life, or loss of an important sustaining relationship. Two investigators attempted to correlate personal and social factors with the progression of the disease. Baldwin (1952) found that depression, which was 
the predominant pattern in almost all cases of multiple sclerosis, was directly related to the length and degree of progression of the disease process. Wullstein (1957), in a study of over 4,800 cases of multiple sclerosis, concluded that the course of the disease was influenced, at least to a limited degree, by occupation, social position, military service, or previous illness or accidents.

Interest in these questions in cases of cancer, judging from the number of publications, has been even more intense (Le Shan and Worthington, 1956a, b). Patients with cancer have been characterized as being subject to sudden stresses such as the loss of an important sustaining relationship, as showing evidence of despair, as being unable to discharge their feelings directly and thus showing high levels of anxiety, as being victims of prolonged frustration and/or lack of satisfaction, and as showing paranoid tendencies and various other personality problems. There have been several attempts to relate the severity of these and other personality characteristics to the rapidity of progression of malignant growth (Gengerelli and Kirkner, 1954). Blumberg and his collaborators suggested that rapidly progressing cancer cases were characterized by a high degree of defensiveness, a high amount of anxiety and depression, and an abnormal lack of ability to decrease anxiety through some outward corrective action (Blumberg, West, and Ellis, 1954). Perrin and Pierce (1959) have criticized these studies, but appear to take seriously the possibility that patients with fast-growing cancers are more defensive, more inhibited, and more anxious than patients with slow-growing cancers. Klopfer (1957) has suggested that:

If a good deal of the vital energy that the patient has at his disposal is used up in the defence of an insecure ego, then the organism seems not to have the vital energy at his disposal to fight the cancer off. If, however, a minimum of vital energy is consumed in ego defensiveness, then the cancer has a hard time making headway.

Using this and other criteria Klopfer was able to differentiate significantly between patients with fast and slow-growing tumours on the basis of their Rorschach protocols. Renneker, Cutler, Hora, Bacon, Bradley, Kearney, and Cutler (1963) suggest that depressive reactions may decrease host resistance, and Shrifte (1962) that cancer patients with a poorer prognosis tend to put more into the outside world than they take from it.

Our results are basically, although not totally, consistent with those relating rapidity of progression of malignant growth to personality factors in cancer. Patients with rapidly-progressing rheumatoid arthritis and patients with rapidly-progressing malignant growth tended to invest a high amount of energy in ego-defensiveness and to show evidence of defence failure as indicated by increasing degrees of anxiety and depression. The rapidly-progressing arthritic patients were, on the other hand, less inhibited than those with slowly-progressing disease, a finding seemingly in direct contradiction to that in cancer. It is likely that this difference is related to the relationship between the stage of progression of a disease and the time of psychological evaluation. The cancer patients were, in general, evaluated early in the disease process, and, at that stage, their ego defensive mechanisms were still successful enough to ward off problems or control of impulses. It is possible, had they been evaluated later, that their defensive mechanisms would have been less successful and that they would therefore have manifested difficulties with impulsivity, as did our rapidly-progressing arthritic patients, who were generally evaluated quite late in the disease process.

Our results were also comparable to those of Baldwin (1952), who found a positive relationship between depression and the length and degree of progression of multiple sclerosis. The patients with rapidly-progressing rheumatoid arthritis had higher scores (although not quite to a statistically significant degree) on the depression and lassitude-malaise scales than those whose disease had progressed more slowly.

It is not clear to what extent the particular personality factors mentioned as related to rapidity of progression of disease are related to this factor rather than to the degree of incapacity which the patient shows. Similar personality factors differentiated between one group of patients who showed a relatively high degree of functional capacity and another group who showed a relatively low degree of functional capacity (Moos and Solomon, 1963c). Unfortunately, however, because of the relatively small total number of cases available, it was not possible completely to match rapidity of progression in the two groups of our earlier study or grade of capacity in the two groups used in this study. Grade of capacity relative to the progression of the disease state had been matched; however, the patients with rapidly progressing disease were, on an absolute level, functioning more poorly than the patients whose disease had progressed more slowly.

These factors suggest that the results must be interpreted with caution. Answers to questions regarding the reliability of these findings, and the extent to which relevent personality factors are related to the rapidity of progression of disease and 
to the degree of functional capacity of the patient, or to both, must await further research.

It is of course undetermined to what extent the differences in these two groups reflect differences in reaction to the fact of having a chronic disease and to what extent they reflect personality differences present before the onset of illness. The slow progression group, for whatever reasons, were still able to maintain, in the face of the stress of chronically crippling illness, quite adequate adaptation, but those in the rapid progression group were beginning to find the stress potentially highly disruptive and threatening.

The findings may reflect the fact that it is psychologically easier to adapt successfully to a more slowly progressing disease, partly because the patient has longer to mobilize his defensive and adaptive ego resources. One may also see the process as a "vicious circle" in which the high degree of energy (pre-disease) involved in ego defensiveness against anxiety or depression and the rapid progression of the disease mutually enhance and reinforce each other.

The stress of disease may stimulate adaptations which seem, on the surface at least, partially successful. In some patients these defences consume a good deal of the available vital energy, and it seems to be in these patients that the disease progresses more rapidly. This may lead to greater stress, and this may, in turn, lead to a greater expense of energy on defensive mechanisms, and this again to increased rapidity of progression of disease. In this connexion, it is possible that the physiological concomitants of increased anxiety and depression (e.g. high levels of corticosteroids which probably depress lymphocytes and thus antibody formation) may be related to resistance to disease. These and other possible mechanisms will be discussed in a later paper.

\section{Summary}

It has been suggested that particular personality factors may differentiate between rheumatoid arthritic patients whose disease progresses relatively rapidly and those whose disease progresses relatively slowly. Those patients whose disease had progressed most rapidly (shortest duration and greatest severity) and those whose disease had progressed most slowly (longest duration and least severity) were selected from a larger sample and compared on an objective psychological inventory.

The patients with relatively slow disease progression scored higher on scales reflecting compliancesubservience, perfectionism, denial of hostility, capacity for status, social responsibility and social status; whereas those with relatively rapid disease progression scored higher on scales reflecting physical malfunctioning, general maladjustment, judged anxiety, judged manifest hostility and imperturbability.

It is suggested that the patients whose disease was progressing most rapidly were experiencing feelings of ego disorganization with concomitant increase in anxiety and depression and decrease in the ability to continue former modes of psychological adaptation and coping. Data relating progression of disease to personality factors in multiple sclerosis and cancer are reviewed and it is suggested that the process may be regarded as a "vicious circle" in which the high degree of energy involved in ego defensiveness and the rapid progression of the disease mutually enhance and reinforce each other.

Part of this research was conducted during the senior author's tenure at a postdoctoral fellowship in the Interdisciplinary Program for Research in the Basic Sciences Related to Mental Health, and the junior author's tenure as a USPHS career teacher in psychiatry, both at the University of California School of Medicine, San Francisco.

The research was supported in part by funds made available from USPHS Grants $2 \mathrm{M}-7082$ and $2 \mathrm{M}-7552$, and by a grant from the Northern California Chapter of the Arthritis and Rheumatism Foundation.

Particular appreciation is due to Dr. Ephraim P. Engleman and the Rheumatic Disease Group, Department of Medicine, University of California Medical Center, San Francisco, for making the patients available for the investigation, to Dr. Curtis Hardyck and Bernice S. Moos for their exceedingly helpful consultation on computer analysis of the data, and to Eleanor Vaughn and Dr. Hector Boffi for valuable help in various phases of the investigation.

\section{REFERENCES}

American Rheumatism Association (1959). "Primer on the Rheumatic Diseases." The Arthritis and Rheumatism Foundation, New York.

Baldwin, M. V. (1952). J. nerv. ment. Dis., 115, 299.

Blumberg, E. M., West, P. M., and Ellis, F. W. (1954). Psychosom. Med., 16, 277.

Gengerelli, J. A., and Kirkner, F. J. (eds.), (1954). " "The Psychological Variables in Human Cancer". University of California Press, Los Angeles.

Hathaway, S. R., and McKinley, J. C. (1951). "Minnesota Multiphasic Personality Inventory Manual", rev. ed. Psychological Corporation, New York.

Johnson, A., Shapiro, L. B., and Alexander, F. (1947). Psychosom. Med., 9, 295.

King, S. H. (1955). J. chron. Dis., 2, 287.

and Cobb, S. (1959). Arthr. and Rheum., $2,322$.

Klopfer, B. (1957). J.proj. Tech., 21, 331. 
LeShan, L., and Worthington, R. E. (1956a). Brit. J. med. Psychol., 29, 49.

(1956b). J. nerv. ment. Dis., 124, 460.

Moos, R. H. (1964). J. chron. Dis., 17, 41.

and Solomon, G. F. (1963a, b, c). Unpublished studies.

(1964). J.psychosom. Res. (in press).

Perrin, G. M., and Pierce, I. R. (1959). Psychosom. Med., 21, 397.

Renneker, R. E., Cutler, R., Hora, J., Bacon, C., Bradley, G., Kearney, J., and Cutler, M. (1963). Ibid., 25, 106.

Scotch, N. A., and Geiger, H. J. (1962). J. chron. Dis., $15,1037$.

Shrifte, M. L. (1962). Psychosom. Med., 24, 390.

Steinbrocker, O., Traeger, C. H., and Batterman, R. C. (1949). J. Amer. med. Ass., 140, 659.

Warner, W. L., Meeker, M., and Eells, K. (1949). "Social Class in America: A Manual of Procedure for the Measurement of Social Status." Science Research Associates, Chicago.

Welsh, G. S., and Dahlstrom, W. G. (eds) (1956). "Basic Readings on the MMPI in Psychology and Medicine." University of Minnesota Press, Minneapolis.

Wright, V. (1963). J. chron. Dis., 16, 83.

Wullstein, O. (1957). Excerpt. med., Sect. 8, 10, 30. "VI int. Congr. Neurol., Brussels, 1957."

\section{La personalité en fonction de la vitesse d'évolution de l'arthrite rhumatismale}

\section{RÉSUMÉ}

Il a été postulé que des facteurs particuliers de personalité peuvent différentier entre des patients atteints d'arthrite rhumatismale à évolution relativement rapide et ceux dont la maladie évolue relativement lentement. Des patients dont la maladie avait évolué le plus rapidement (la plus courte durée, la plus grande sévérité) et ceux dont la maladie avait évolué le plus lentement (la plus longue durée et la moindre sévérité) ont été choisis d'entre un grand nombre de malades et comparés à l'aide d'une échelle psychologique objective.

Les malades atteints d'arthrite à évolution relativement lente ont marqué plus de points quand il s'agissait de: conformité-asservissement, perfectionisme, déni d'hostilité, capacité pour status, responsabilité sociale et rang social; par contre, les malades atteints d'arthrite à évolution relativement rapide ont marqué plus de points quand il s'agissait de: désordre de la fonction physique, mauvais ajustement général, anxiété jugée, hostilité manifeste jugée et imperturbabilité.

On pense que les patients dont la maladie évoluait très rapidement éprouvaient la sensation de désorganisation de l'égo avec augmentation concomitante de l'anxiété et de la dépression et avec diminution de la capacité de maintenir leur modes d'adaptation psychologique et de faire face aux difficultés. On passe en revue les faits concernant l'évolution morbide par rapport aux facteurs de personalité dans la sclérose en plaques et dans le cancer et on pense qu'il peut s'agir ici d'un "cercle vicieux", où beaucoup d'énergie appliquée à l'action défensive de l'égo et l'évolution rapide de la maladie s'augmentent et se renforcent mutuellement.

\section{La personalidad en función de la rapidez de evolución de la artritis reumatoide}

\section{Sumario}

Se ha sugerido que factores particulares de personalidad pueden diferenciar entre pacientes con artritis reumatoide cuya enfermedad sigue un curso relativamente rápido y aquellos cuya enfermedad sigue un curso relativamente lento. Pacientes cuya enfermedad había progresado más rápidamente (menor duración y mayor severidad) y los cuya enfermedad había adelantado más depacio (mayor duración $y$ menor severidad) fueron elegidos de un mayor grupo de enfermos y comparados con la ayuda de una escala psicológica objetiva.

Los enfermos con artritis de evolución relativamente lente marcaron más puntos al tratarse de: conformidadsumisión, perfeccionismo, denegación de hostilidad, capacidad de mantener su posición social (status), responsabilidad social y nivel social; en cambio, los con artritis de evolución relativamente rápida marcaron más puntos al tratarse de: trastorno de la función física, mal ajustamiento general, ansiedad juzgada, hostilidad manifiesta juzgada e imperturbabilidad.

Se sugiere que los pacientes cuya enfermedad adelantaba muy rápidamente percibían la sensación de desorganización del ego con aumento concomitante de ansiedad y de depresión y con disminución de la capacidad de mantener sus modos de adaptación psicológica y de hacer frente a las dificultades. Se repasan los datos respecto a la relación entre la evolución de la enfermedad y los factores de personalidad en la esclerosis diseminada y en el cancer y se sugiere que se trata aquí de un "círculo vicioso", en que mucha energía aplicada a la acción defensiva del ego y la evolución rápida de la enfermedad se aumentan y reforzan mutualmente. 